\title{
Phytochemical Screening of Methanolic, Pet Ether and Ethyl Acetate Extracts of Helicteres isora Linn
}

\author{
Sunny Sharma ${ }^{1}$, Seema Bhargava ${ }^{2}$, Kalu Singh Chundawat ${ }^{3}$ \\ ${ }^{1,2,3}$ Department of Biotechnology, Mewar University Gangrar, Chittorgarh, Rajasthan, India
}

\begin{abstract}
Helicteres isora is well known for its use in herbal medicine and it is said to possess many medicinal values. The present study was designed for screening phytochemicals in three different extracts (Pet Ether, Ethyl Acetate, and Methanol). Phytochemical screening was performed to detect the presence of alkaloids, carbohydrates, reducing sugar, flavonoids, glycoside, tannin, phenolic compound, saponin, proteins, amino acid, triterpenoids and steroids. Ethyl acetate extract was found to be phytochemically richer as compared to Pet Ether and Methanolic extract. The reducing sugar and saponin were not detected in these extracts. A good quantity of the phytochemicals may contribute to the medicinal and nutritive values of Helicteres isora.
\end{abstract}

Keywords: Helicteres isora, Methanol, Pet ether, Ethyl acetate, Soxhlet

\section{Introduction}

Therapeutic use of herbs and their phytochemicals have always fascinated researchers all over the world. Herbs and their agents have been a source of medicine since, the Vedic period. Modern medicines are mostly isolated from plant based agents, depending on the traditional medical knowledge ${ }^{1}$. Thus, plants and herbs contribute a major share in traditional and modern medicinal system for health care. The bioactive compounds present in plants like alkaloids, flavonoids, tannins and phenolic compounds are the source of its medicinal value that produces a definite physiological and biochemical action on the body ${ }^{2}$.Helicteres isora linn belongs to the family Sterculiaceae. It has been frequently used as an astringent and blood-purifer ${ }^{3}$. It is commonly found in India from Jammu eastwards to Nepal, Bihar, Central, Western and Southern India, West Bengal, and the Andaman islands. Due to screw like appearance of its fruit it is commonly known as Enthani, Marodphali, Marorphali, etc. It is a medium size tree attaining a maximum high of $5 \mathrm{~m}$. It is shown in Literature that Helicteres isora plant shows antioxidant, anti-inflammatory, antipyretic, and antispasmodic $^{4-5}$ activities. presence of flavones ${ }^{6}$, triterpenoids ${ }^{7}$, cucurbitacin ${ }^{8}$, phytosterols, saponins, sugars and phlobatannins. The root and stem barks are considered to be expectorant, demulcent, astringent and antigalactagogue and are useful in colic, scabies, empyema, gastropathy, diabetes, diarrhea and dysentery ${ }^{9}$. The fruits are astringent, acrid, refrigerant, demulcent, constipating, stomachic, vermifuge, vulnerary, haemostatic and urinary astringent. They are useful in vitiated conditions of pitta ophthalmitis, colic, flatulence, diarrhea, dysentery, verminosis, wounds, ulcers, hemorrhages, epistaxis and diabetes ${ }^{10}$.

\section{Material and Methods}

Helicteres isora plant material was collected from central India. Herbarium of plant was prepared and submitted for authentication. The plant material was shade dried and was further processed from extraction processes.

\subsection{Extraction}

Dried and powdered raw material was defatted with petroleum ether than soxhleted with ethyl acetate and methanol. The extraction was carried out by soxhletion to complete extraction.

\subsection{Phytochemical screening}

Detailed phytochemical testing was performed to identify presence or absence of different phyto-constituents. We used more than one test for confirmation. Tests are carried out as per the procedure mention in the lab protocol ${ }^{11}$ which are internationally referenced procedures.

\subsubsection{Tests for Alkaloids}

To the extract, dilute hydrochloric acid was added, shake it well and filtered. With the filtrate, the following tests were performed.

\subsubsection{Mayer's Test}

To 2-3 ml of filtrate, few drops of Mayer's reagent were added along sides of tube. Formation of white or creamy precipitate indicates the presence of alkaloids.

\subsubsection{Wagner's Test}

To 1-2 ml of filtrate, few drops of Wagner's reagent were added in a test tube. Formation of reddish brown precipitate indicates the presence of alkaloids.

\subsubsection{Hager's Test}

To 1-2 ml of filtrate, few drops of Hager's reagent were added in a test tube. Formation of yellow color precipitate indicates the presence of alkaloids.

\subsection{Tests for Carbohydrates}

2.3.1 Molish Test: $2 \mathrm{ml}$ of aqueous extract was treated with 2 drops of alcoholic $\alpha$-naphthol solution in a test tube and then $1 \mathrm{ml}$ of concentrated sulphuric acid was added carefully along the sides of the test tube. Formation of violet ring at the junction indicate the presence of carbohydrates. 


\section{International Journal of Science and Research (IJSR) \\ ISSN (Online): 2319-7064}

Index Copernicus Value (2015): 78.96 | Impact Factor (2015): 6.391

2.3.2 Barfoed's Test: $1 \mathrm{ml}$ of extract and Barfoed's reagent were mixed in a test tube and heated on water bath for 2 minutes. Red colour due to formation of cupric oxide indicates the presence of monosaccharide.

\subsection{Tests for Reducing Sugar}

\subsubsection{Fehling's Test}

To $1 \mathrm{ml}$ of aqueous extract, $1 \mathrm{ml}$ of Fehling's A and $1 \mathrm{ml}$ of Fehling's B solutions were added in a test tube and heated in the water bath for 10 minutes. Formation of red precipitate indicates the presence of reducing sugar.

\subsubsection{Benedict's Test}

Equal volume of Benedict's reagent and extract were mixed in a test tube and heated in the water bath for 5-10 minutes. Solution appears green, yellow or red depending on the amount of reducing sugar present in the test solution which indicated the presence of reducing sugar.

\subsection{Tests for Flavonoids}

\subsubsection{Alkaline Reagent Test}

The extract was treated with few drops of sodium hydroxide separately in a test tube. Formation of intense yellow color, which becomes color less on addition of few drops of dilute acid, indicate presence of flavonoids.

\subsubsection{Lead Acetate Test}

The extract was treated with few drops of lead acetate solution. Formation of yellow precipitate may indicate the presence of flavonoids.

\subsubsection{Shinoda test}

To the extract, $5 \mathrm{ml}(95 \%)$ of ethanol was added. The mixture was treated with few fragments of magnesium turning, followed by drop wise addition of concentrated hydrochloric acid. Formation of pink color indicates presence of flavonoids.

\subsection{Tests for Glycosides}

\subsubsection{Borntrager's Test}

To $3 \mathrm{ml}$ of test solution, dilute sulphuric acid was added, boiled for 5 minutes and filtered. To the cold filtrate, equal volume of benzene or chloroform was added and shake it welled. The organic solvent layer was separated and ammonia was added to it. Formation of pink to red color in ammonical layer indicates presence of anthraquinone glycosides.

\subsubsection{Legal's Test:}

$1 \mathrm{ml}$ of test solution was dissolved in pyridine. $1 \mathrm{ml}$ of sodium nitropruside solution was added and made alkaline using $10 \%$ sodium hydroxide solution. Formation of pink to blood red color indicates the presence of Cardiac glycosides.

\subsubsection{Keller-Killiani Test}

To $2 \mathrm{ml}$ of test solution, $3 \mathrm{ml}$ of glacial acetic acid and 1 drop of $5 \%$ ferric chloride were added in a test tube. Add carefully $0.5 \mathrm{ml}$ of concentrated sulphuric acid by the side of the test tube. Formation of blue color in the acetic acid layer indicates the presence of Cardiac glycosides.

\subsection{Tests for Tannin and Phenolic compounds}

\subsubsection{Ferric Chloride Test}

Some amount of extract was dissolved in distilled water. To this solution $2 \mathrm{ml}$ of $5 \%$ ferric chloride solution was added. Formation of blue, green or violet color indicates presence of phenolic compounds.

\subsubsection{Lead Acetate Test}

Some amount of extract was dissolved in distilled water. To this solution few drops of lead acetate solution was added. Formation of white precipitate indicates presence of phenolic compounds.

\subsubsection{Dilute Iodine Solution test}

To 2-3 $\mathrm{ml}$ of extract, few drops of dilute iodine solution were added. Formation of transient red color indicates presence of phenolic compounds.

\subsection{Tests for Saponins}

\subsubsection{Froth Test}

The extract was diluted with distilled water and shaken in graduated cylinder for 15 minutes. The formation of layer of foam indicates the presence of saponins.

\subsection{Tests for Protiens and Amino Acids}

\subsubsection{Ninhydrin Test}

$3 \mathrm{ml}$ of the test solution was heated with 3 drops of $5 \%$ Ninhydrin solution in a water bath for 10 minutes. Formation of blue colour indicates the presence of amino acids.

\subsubsection{Biuret's Test}

The extract was treated with $1 \mathrm{ml}$ of $10 \%$ sodium hydroxide solution in a test tube and heated. A drop of $0.7 \%$ copper sulphate solution was added to the above mixture. The formation of violet or pink colour indicates the presence of proteins.

\subsubsection{Million's Test}

$3 \mathrm{ml}$ of extract was mixed with $5 \mathrm{ml}$ of Million's reagent. White precipitate formed which on heating turned to brick red, indicating the presence of proteins.

\subsection{Tests for Triterpenoids and Steroids}

\subsubsection{Salkowski's Test}

The extract was treated with chloroform and filtered. The filtrate was added with few drops of concentrated sulphuric acid, shaken and allowed to stand. If the lower layers turns red, sterol are present. Presence of golden yellow layer at bottom indicates the presence of triterpenes.

\subsubsection{Libermann-Burchard's Test}

The extract was treated with chloroform. To this solution few drops of acetic anhydride were added, boiled and cooled. Concentrated sulphuric acid was added through the sides of the test tube. Formation of brown ring at the junction of two layers, if upper layer turned green, indicate presence of steroids and formation of deep red color indicate presence of triterpenoids.

Volume 6 Issue 1, January 2017 
International Journal of Science and Research (IJSR)

ISSN (Online): 2319-7064

Index Copernicus Value (2015): 78.96 | Impact Factor (2015): 6.391

\section{Results}

Table 1: Phytochemical evaluation

\begin{tabular}{|l|l|l|l|}
\hline & PEE & EAE & ME \\
\hline 1. Alkaloids & + & + & + \\
\hline Mayer's reagent test & + & + & + \\
\hline Wagner's reagent test & + & + & + \\
\hline Hager's reagent test & - & + & + \\
\hline 2. Carbohydrates & - & + & + \\
\hline Molish's test & - & - & - \\
\hline Barfoed's test & - & - & - \\
\hline 3. Reducing Sugar's & - & + & + \\
\hline Fehling's test & - & + & - \\
\hline Benedict's test & - & + & - \\
\hline 4. Flavonoids & - \\
\hline Alkaline reagent test & - & - & + \\
\hline Shinoda test & - & - & + \\
\hline Lead acetate test & - & - & + \\
\hline 5. Glycoside & - & \\
\hline Borntrager test & - \\
\hline Legal's test & - & + & - \\
\hline Killer- Killiani test & - & + \\
\hline 6.Tannin and Phenolic compound \\
\hline Ferric chloride test & - & + & - \\
\hline Lead Acetate test & - & + & - \\
\hline Dilute Iodine solution & - & + & + \\
\hline 7. Saponin & - & + & + \\
\hline Foam Test & - & - \\
\hline 8. Proteins and amino acid & - & - & - \\
\hline Ninhydrin test & + & + \\
\hline Biuret's Test & - & + & + \\
\hline Million's Test & - Triterpenoids and Steroids \\
\hline Salwonski Test & + & + \\
\hline Libberman and Burchard's test & - & + \\
\hline
\end{tabular}

PEE Pet ether extract, EAE- Ethyl acetate Extract, MEMethanolic extract.

$(+)$ indicates presence and $(-)$ indicates absence

Above table shows the results of phytochemical analysis of Helicteres isora.

\section{Discussion}

Different medicinal plants and their products have been reported to be good sources of phytochemicals. The phytochemical analysis conducted on the Pet ether, Ethyl acetate and methanolic extract of $H$. Isora revealed the presence of alkaloids, carbohydrates, flavonoids, glycoside, tannin and phenolic compounds, triterpenoids, proteins and amino acids. Whereas, reducing sugar and saponin were not detected in all these extracts; flavonoids and phenolic compound were absent in Pet ether extract. These phytochemicals have been shown to play protective roles against various chronic diseases ${ }^{12}$. The phytochemicals including polyphenols, flavonoids and triterpenoids were found to be more important for study as they have profound effects on human health ${ }^{13}$. Tannins are known to be useful in the treatment of inflamed or ulcerated tissues and they have remarkable activity in cancer prevention and acts as natural anticancer agents ${ }^{14}$. Phenolic compounds show the ability as a potent chain breaking antioxidants ${ }^{15}$.It was shown that polyphenolic compounds are anti-mutagenic and inhibits carcinogenesis in humans, when ingested up to $1 \mathrm{~g}$ daily from a diet rich in fruits and vegetables ${ }^{16}$. Flavonoids present in food of plant origin are also potential antioxidants ${ }^{17}$. The results show good quantities of phytochemicals which may help in formulating new drugs.

\section{Conclusion}

There is enormous amount of phytochemicals present in Helicteres isora andcan be used as an effective drug against various chronic diseases. In addition to this, the methanolic and ethyl acetate extract of Helicteres isora contains significant amounts of phenols and flavonoids, which can play a major role in management of oxidation. The data found in this work might be useful for further study of the Helicteres isora plant products and plant as whole on various applications such as nutritive supplement and pharmaceutical benefits.

\section{References}

[1] SharmaM, Thakur Bais R, Preliminary Phytochemical Screening of Methanolic Extracts of Green Grapes and Black Grapes (VitisviniferaL.) International Journal of Science and Research(IJSR),2015, 220-222

[2] Hemashenpagam N, LaliGrowther, Sankar, Selvaraj T and Panneerselvam A. Photochemical Analysis and Antimicrobial Activity Of Solanumxanthocarpum. Biomedicine. 2009; 29 (4): 353-356.

[3] Khare CP. Encyclopedia of Indian medicinal plants.Springer publication. 2004.p.244-245.

[4] Tiwari V, Tiwari A, Madhavan V. Preliminary phytochemical anaylis, HPTLC studies and antipyretic ctivity of alchol and aqueous extract of Helicteres isora $\mathrm{L}$ root. International Journal of pharmacy and Pharmaceutical Science 2010;2(2);74-79

[5] Badgujar VB, Jain Ps, Badgujar SV. Antifungal activity of stem bark of Helicters isora linn. Drug Invention Today. 2009;1(2)135-136.

[6] Ramesh S and Yuvrajan CR, J. of Natural Products, 1995; 58(8):1242-43.

[7] Dan S and Dan SS, Fitoterpia, 1988; 59(4): 348-49.

[8] M. F. Bean, M. Antoun, D. Abramson, C. J. Chang, J. L. Laughlin, J. M. Cassady, J. Natural Products, 1988; 48(3), 500.

[9] Warrier PK and Nambiar VPK, Indian Medicinal Plants, Orient Longman Ltd.,1955; 3:132-35.

[10] Winter CA, Risley CA and Nus GW, Proc. Soc. Exp. Biol. Med, 1965; 151-62.

[11] Kokate C.K., Purohit A.P., and Gokhale S.B. Pharmacognosy; 23 ed., Niraliprakashan: 2006; pp:493-497.

[12] T sao R, Deng Z. Seperation procedures for naturally occurring antioxidant phytochemicals. J Chromatogr B. 2004; 12:85-99.

[13] Motar MLR, Thomas G, BarbosaFillo JM: Effects of Anacardiumoccidentalestem bark extract on in vivo inflammatory models. J Ethnopharm.1985; 95(2-3):139142.

[14] Hatano T, Edamatsu R and Mori A, Effect of interaction of tannins with co-existing substances, VI, Effects of tannins and related polyphenols on superoxide anion

Volume 6 Issue 1, January 2017 


\section{International Journal of Science and Research (IJSR) \\ ISSN (Online): 2319-7064}

Index Copernicus Value (2015): 78.96 | Impact Factor (2015): 6.391

radical and on DPPH radical, Chem Pharm Bull, 1989, 37, 2016-2021.

[15] Shahidi F and Wanasundara PKJPD, Phenolic antioxidants, Food SciNutr, 1992, 32, 67-103.

[16] Tanaka M, Kuei CW and Nagashima Y, Application of antioxidativemaillrad reaction products from histidine and glucose to sardine products, Nippon Suisan Gakkaishi, 1998, 47, 1409-1414.

[17] Salah N, Miller NJ, Paganga G, Tijburg L, Bolwell GP and Rice Evans C, Polyphenolic flavonols as scavengers of aqueous phase radicals and as chain-breaking antioxidants, Arch BiochemBiophys, 1995, 322(2), 339346

Volume 6 Issue 1, January 2017

www.ijsr.net 